\title{
INSPIRASI ORIGAMI DALAM DESAIN LOGO
}

\author{
Vera Waradya; Arjo Bimo \\ Jurusan Desain Komunikasi Visual, School Of Design, BINUS University \\ Jln. K. H. Syahdan No. 9, Palmerah, Jakarta Barat 11480 \\ waradya@yahoo.com; obeems@binus.ac.id
}

\begin{abstract}
From time to time design trends have adapted in certain styles. One is the art of origami. It inspires many graphic designers in 2009, mainly design logo and typeface. Origami is the traditional Japanese folk art of paper folding, turning a piece of paper into a beautiful shape that is a work of art in itself. And with its simplicity and geometric shapes, origami logo design is used by companies who want to represent modern, delicacy, attention to detail, precision, and elegance.
\end{abstract}

Keywords: logo, graphic design, Japan, origami

\begin{abstract}
ABSTRAK
Dari waktu ke waktu tren desain mengadaptasi gaya tertentu. Salah satunya adalah seni origami yang menginspirasi banyak desainer grafis di tahun 2009, terutama desain logo dan jenis huruf. Origami adalah seni tradisional melipat kertas rakyat Jepang, yaitu mengubah, lebih tepatnya melipat, selembar kertas menjadi suatu bentuk yang indah yang merupakan karya seni tersendiri. Dan dengan kesederhanaan dan bentuk geometrisnya, desain logo origami digunakan oleh perusahaan-perusahaan yang ingin memproyeksikan sifatsifat modern, kehalusan rasa, detail, persisi dan elegan.
\end{abstract}

Keywords: logo, graphic design, Jepang, origami 


\section{PENDAHULUAN}

Origami adalah seni tradisional melipat kertas rakyat Jepang. Kata origami adalah kata dalam bahasa Jepang yang berasal dari dua kata: 'ori' dan 'kami'. 'Ori' artinya melipat, sementara 'kami' artinya kertas.

Sebenarnya origami tidak dimulai di Jepang, melainkan dimulai dari Cina pada abad pertama atau kedua dan kemudian menyebar ke Jepang sekitar abad keenam dan terus berkembang. Pada awalnya hanya ada sedikit kertas dalam jumlah terbatas, sehingga hanya kalangan tertentu dan orangorang kaya yang dapat melakukan kegiatan ini.

Orang Jepang menemukan banyak kegunaan dari origami ini. Sebagai contoh, para samurai bertukar hadiah dalam bentuk 'noshi', yaitu lipatan kertas yang berisi ikan atau daging yang dikeringkan sebagai tanda keberuntungan. Sementara bangsawan Shinto merayakan pernikahan dengan membungkus gelas sake atau beras dengan lipatan kertas berbentuk kupu-kupu untuk mewakili pengantin.

Seiring dengan perkembangan kemudahan dalam pembuatan kertas, kertas menjadi lebih murah dan dapat dijangkau berbagai kalangan dan origami pun menjadi seni populer untuk semua orang. Selama berabad-abad tidak ada petunjuk tertulis mengenai diagram lipatan origami. Cara melipat hanya diajarkan turun temurun dari generasi ke generasi, yang menjadikannya salah satu seni warisan budaya masyarakat Jepang.

Barulah pada tahun 1797 diterbitkan buku origami tertua 'Hiden Senbazuru Orikata' (Rahasia cara melipat 1000 burung bangau)', yang berisi petunjuk cara melipat burung bangau (tsuru). Tsuru adalah burung bangau Jepang yang dianggap rakyat Jepang sebagai symbol keberuntungan dan umur panjang, juga kesetiaan karena burung bangau Jepang dikenal hanya satu kali kawin seumur hidupnya.

Pada tahun 1845 diterbitkan 'Jendela di Tengah Musim Dingin' yang memuat 150 model origami. Salah satunya model katak yang terkenal sampai sekarang. Dengan adanya kedua buku ini, melipat kertas menjadi kegiatan rekreasi yang menyenangkan di Jepang.

Seiring perkembangan zaman fungsi origami semakin beragam. Dengan banyaknya kreasi lipatan-lipatan baru yang kreatif dan modern, selain untuk simbol-simbol, origami juga dapat dimanfaatkan langsung untuk kebutuhan sehari-hari manusia. Selain dari Jepang, para ahli melipat kertas bermunculan dari banyak tempat di seluruh dunia. Salah satu tokoh 'Bapak Origami Modern' adalah Akira Yoshiwara dengan lipatan kertasnya yang sangat kreatif. Beliau pula yang mengembangkan rangkaian simbol dan istilah dalam instruksi tertulis origami yang digunakan di seluruh dunia.

Origami juga banyak menginspirasi desainer-desainer di dunia dengan mengaplikasikannya pada desain pakaian, desain perhiasan, arsitektur, desain interior, desain produk dan desain grafis. Dan salah satunya yang akan dibahas disini adalah desain logo.

\section{Logo}

Logo adalah sebuah simbol yang mengandung banyak arti dan filosofi. Sebuah desain logo mencerminkan jati diri sebuah perusahaan dan menjadi pembeda visual suatu perusahaan dengan perusahaan lainnya. Fungsi Logo: 1) Menyampaikan citra positif perusahaan dan menunjukkan kegiatan perusahaan yang diwakilinya. Karena itu, logo harus didesain unik (berbeda dari desain logo perusahaan lainnya), jelas dan sederhana (mudah dipahami yang diwakilinya) serta tidak 
membingungkan orang yang melihatnya, layak atau sesuai (desain mencerminkan citra dan fungsi perusahaan yang diwakilinya dengan baik) dan tidak menimbulkan kesan yang salah, dan indah (desain yang indah akan menyenangkan bagi yang melihat dan menarik untuk diingat. 2) Berperan memberikan kesan baik pada masyarakat. Logo yang disukai cukup memengaruhi minat dan kepercayaan masyarakat untuk mencoba produk atau jasa yang ditawarkan.

\section{METODE PENELITIAN}

Penelitian yang dilakukan berdasarkan studi literatur dan elektronik dengan mencari berbagai sumber terkait proses mendesain logo dan seni origami. Penulis juga melakukan pendekatan studi kaji dengan menghadiri workshop dan pengamatan pribadi. Sumber informasi diseleksi, dievaluasi, dan dijadikan pendukung dalam penulisan ini.

\section{HASIL DAN PEMBAHASAN}

Logo

Unsur-unsur grafis pada logo adalah sebagai berikut.

\section{Tipografi}

Tipografi adalah gambar dari kata-kata. Letterform disusun untuk menyampaikan suatu pesan. Sikap, sejarah, dan kultur suatu perusahaan tercermin dari letterform sebuah logo. Memilih jenis huruf untuk sebuah logo adalah tugas yang kompleks. Hal-hal yang perlu dipertimbangkan dalam memilih tipografi dalam logo adalah kombinasi bentuk huruf yang digunakan, bail dengan satu jenis huruf maupun kombinasi beberapa jenis huruf; keterbacaan (legibility dan readability), spasi, kerning, leading; pembedaan suara yang timbul ketika kata-kata diucapkan; latar belakang dan sejarah jenis huruf yang digunakan.

\section{Warna}

Warna bersifat subjektif dan memberikan ikatan emosional dan memengaruhi personal yang melihat, karena itu warna sangatlah penting dalam desain logo. Menurut pakar desain Dabner (2003), pilihan warna dapat menimbulkan efek luar biasa pada suatu desain dan bagaimana orang meresponsnya (feedback). Karena itu, sangat penting mengetahui arti dan efek psikologis yang dapat ditimbulkan oleh warna.

\section{Image/Iconography}

Icon dapat sangat kuat dan menyampaikan banyak informasi secara cepat. Berdasarkan Adams (2004) ada beberapa jenis ilustrasi: Diagramatik, bahwa icon mewakilkan tatatanan atau struktur subjek yang ingin digambarkan; Metaphorik, bahwa gambar/image berdasarkan konsep yang behubungan; Simbolik, gambar/image abstrak yang tidak ada hunungan dekat dengan subjeknya.

\section{Bentuk (Shape)}

Logo yang baik akan melibatkan bentuk yang cocok dan mudah diingat. Ukuran dan perbedaan bentuk dapat menyampaikan kepentingan dan pengaruh yang kuat. Masing-masing bentuk 
memiliki karakteristik tersendiri. Bentuk dibagi menjadi tiga golongan bentuk dasar, yaitu segitiga, segi empat atau kotak, dan lingkaran. Yang dimaksud dengan shape di sini adalah seluruh bentuk dari logo tersebut, bukan hanya dilihat dari image/ikon saja. Berikut jenis-jenisnya. Pertama, bentuk kotak: memberikan kesan kesatuan yang kuat. Kedua, bentuk lingkaran: memberikan kesan tanpa batas, dan perlindungan. Ketiga, bentuk segitiga: memberikan kesan dinamis, dapat pula dihubungkan dengan bentuk-bentuk umum, seperti: piramid, bendera, panah, atau pointer.

Tipe-tipe Logo adalah Wordmark (logotype), yaitu logo yang menggunakan nama perusahaan dengan tipografi khusus atau huruf yang unik; Symbol, yaitu logo yang menggunakan gambar atau ikon; dan Monogram, yaitu desain dari satu atau beberapa huruf yang merupakan inisial perusahaan.

\section{Origami Logo}

Logo yang terinspirasi bentuk-bentuk origami secara umum disebut Origami Logo. Pada tulisan ini penulis juga menggunakan istilah tersebut. Desainer menggunakan tema origami atas dasar keinginan untuk kembali ke bentuk dasar. Hal ini dapat dicapai karena bentuk-bentuk dari origami terdiri dari bentuk dasar yang bersiku seperti segitiga, persegi atau trapesium.

Dalam pembuatannya, Origami Logo tidak terlepas dari proses digital yang memindahkan bentuk origami yang tiga dimensi ke bentuk dua dimensi. Karena itu, banyak digunakan blok-blok warna, gradasi warna dan bayangan untuk membedakan bidang-bidang lipatan atau memberikan efek tiga dimensi.

Bentuk origami yang digunakan dalam Origami Logo dapat dibagi dalam 3 grup, yaitu: figur mahluk hidup dan benda, letterforms, bentuk abstrak.

\section{Origami Logo - Figur Makhluk Hidup dan Benda}

Gambar berikut adalah origami logo dari Limver, perusahaan cleaning service dari Spanyol, dengan model origami burung bangau (tsuru), berwarna analogus dari hijau muda ke biru, dan tipe logo symbol.

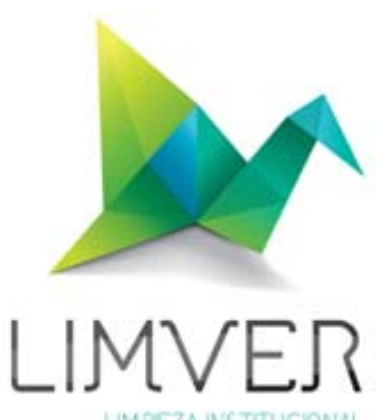

Gambar 1 Desain Logo LIMVER

(Sumber: imbombon.blogspot.com/2010/04/limver-logos.html)

Penggunaan model origami burung bangau mencerminkan sikap yang setia, teliti sesuai dengan filosofi burung bangau dari Jepang. Sementara warna analogus hijau muda ke biru bermakna alami dan menyejukkan. Dengan kata lain, dengan menggunakan jasa dari perusahaan Limver, pelanggan akan mendapatkan kenyamanan dari sikap setia dan teliti dalam menjaga kebersihan. Penggunaan typeface kurang tepat, karena bentuk-bentuk yang melengkung tidak unity dengan bentuk dasar dari origami tsuru ini. 
Selanjutnya adalah origami logo Voerin, perusahaan fashion online shop, dengan model origami bebek/angsa, berwarna oranye, dan tipe logo symbol.

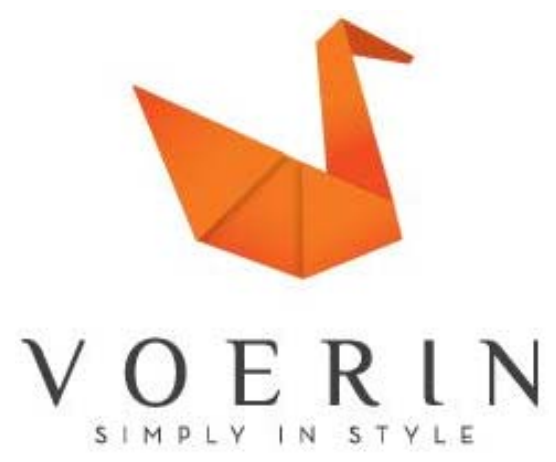

Gambar 2 Desain Logo Voerin

(Sumber: voerin.com)

Penggunaan model origami ini dilatarbelakangi cerita 'ugly duckling', seekor bebek yang tadinya buruk rupa menjelma menjadi angsa yang cantik. Sementara warna oranye memberikan efek yang menarik perhatian, sesuai dengan tujuan penjualan produk fashion yang akan mempercantik dan menjadikan pemakainya pusat perhatian. Penggunaan jenis huruf yang memiliki kait-kait diujungnya, sesuai dengan bagian paruh bebek yang juga membentuk kait.

Gambar berikut ini merupakan logo dari Vilyaiskiy_produckt, sebuah perusahaan produk pertanian dari Rusia, desainer oleh Snowkai, dengan model origami banteng, berwarna vivid color, dengan tipe logo symbol.

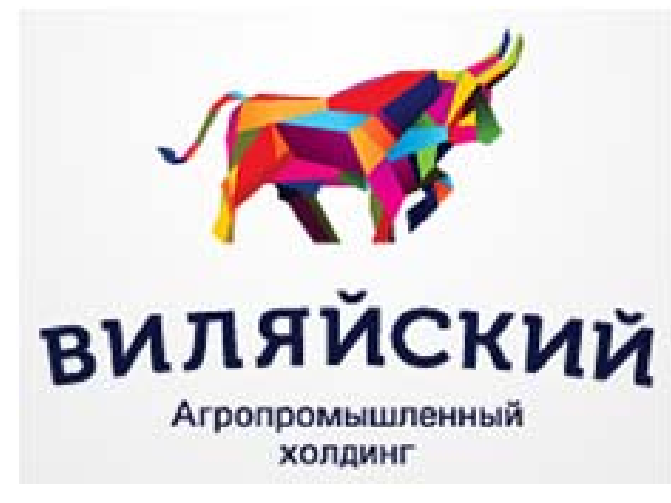

Gambar 3 Desain Logo Vilyaiskiy

(Sumber: logopond.com/gallery/detail/91859)

Logo ini dimaksudkan terinspirasi dari model origami banteng, tetapi penerapan bentuk kurang tepat, karena masih terlihat realistis, masih jauh dari bentuk stilasi yang merupakan ciri khas origami.

Gambar berikut ini merupakan logo Nocturn, perusahaan studio desain grafis, dengan model origami kelelawar, berwarna ungu tua. Tipe logo adalah symbol. 


\section{nociurn}

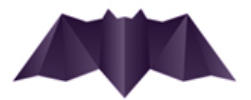

Gambar 4 Desain Logo Nocturn

(Sumber: alextass.com/identity-design/logo-design)

Kelelawar adalah binatang nokturnal, yaitu binatang tidur pada siang hari dan aktif pada malam hari. Pendekatan modern dari model origami kelelawar untuk logo ini mencerminkan aktivitas desainer grafis yang kerap dilakukan malam hari.

\section{Origami Logo - Letterform}

Gambar berikut merupakan logo Kite String Studio, dengan jenis usaha studio fotografi, model origami lipatan kertas membentuk hurus $\mathrm{K}$ dan S, berwarna biru muda. Tipe logo adalah monogram.

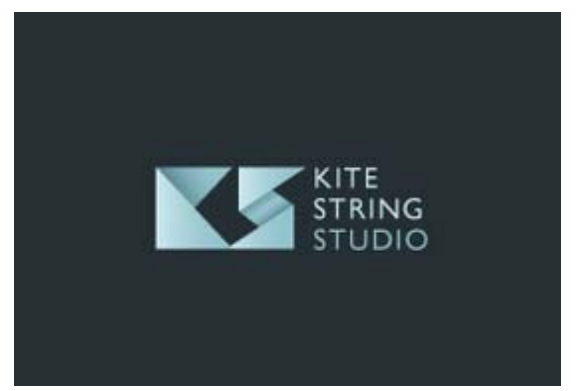

Gambar 5 Desain Logo Kite String Studio (Sumber: eziedesigns.co.uk)

Gambar selanjutnya dalah logo Integra Group, perusahaan grup finansial dengan kapitalis ventura, desainer why-hellothere, dengan model origami lipatan kertas membentuk hurus I dan G, berwarna kromatik hijau. Tipe logo adalah monogram.

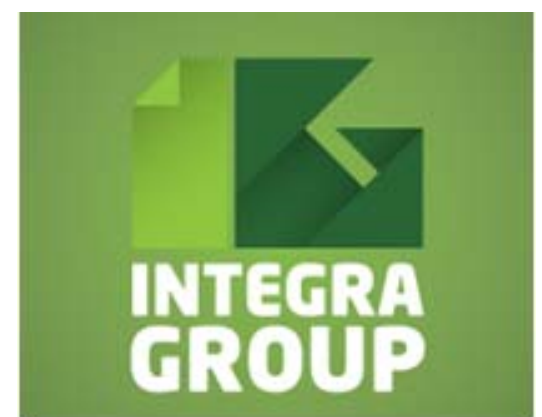

Gambar 6 Desain Logo Integra Group

(Sumber: logopond.com/members/profile/showcase/26735) 


\section{Origami Logo - Bentuk Abstrak}

Selanjutnya adalah origami logo Rostari, jenis usaha solution network, desainer Tini 1, dengan model origami lipatan kertas yang bidang negatifnya membentuk balon kata, berwarna kromatik biru. Tipe logo adalah symbol. Logo yang digambarkan mencerminkan networking, hubungan, dan sharing.

\section{Srostari}

Gambar 7 desain logo Rostari

Sumber: logopond.com/gallery/detail/151385

\section{SIMPULAN}

Karakteristik dari origami dapat diterapkan dalam sebuah desain logo. Hal ini dibuktikan dengan beberapa contoh yang disebutkan pada bab pembahasan. Namun tren desain yang mengambil inspirasi dari bentuk origami ini memang hanya bersifat sementara. Ini karena beberapa hal seperti: ada kecenderungan mirip satu dengan lain karena model origami sangat mudah dikenali dari bentukbentuknya yang geometris dan bersiku; penggunaan bayangan atau gradasi warna menjadikan desain logo agak susah diterapkan apalagi dalam ukuran kecil; tidak semua desain logo pada bab pembahasan memiliki filosofi yang sama dengan model origami yang dipakai. Ini disebabkan beberapa logo teresebut hanya mengambil bentuk dankarakteristiknya saja.

\section{DAFTAR PUSTAKA}

Adams, S. (2004). Logo Desain Workbook: A Hands-on Guide to Creating Logos. Massachusetts: Rockport.

Dabner, D. (2003). How to Understand and Use Design. Second edition. Ohio: Hoe to Design Book.

Kenneway, E. (1987). Complete Origami: An A-Z Facts and Folds, with Step-By-Step $\quad$ Instructions for Over 100 Projects. New York City: St. Martin's Griffin.

Logoorange. (2009). Logo design trends 2009. diakses 13 September 2012 dari http://www.logoorange.com/logo-design-09.php.

Masao, O. The History of Origami in Japan. Diakses 12 September 2012 dari http://www.origami.gr.jp/Archives/People/OKMR_/history-e.html.

Purwanto, B. (2007). Desain Grafis Tata Letak dan Tipografi. Jakarta: Pusat Grafika Indonesia, Diknas. 